\title{
$\mathrm{BDM}$ 기법을 적용한 공동주택 마감공사 TACT공정계획 수립 및 운영
}

\author{
김선규 ${ }^{1} \cdot$ 유재우 ${ }^{\star} \cdot$ 김동섭 $^{1} \cdot$ 박종일 ${ }^{1}$ \\ 1강원대학교 건축공학과
}

\section{TACT Scheduling \& Monitoring of Apartment Finish Works based on the BDM Technique}

\author{
Kim, Seon-Gyoo ${ }^{1}$, Yoo, Jae-Woo ${ }^{*}$, Kim, Dong-Sub ${ }^{1}$, Park, Jong-i1 ${ }^{1}$
}

${ }^{1}$ Department of Architectural Engineering, Kangwon National University

\begin{abstract}
As the recent construction projects have been carried out as a mixed-use complex project that includes architecture, civil, mechanical, electrical, and landscape, as well as become bigger and high-rise with the increased repetitive works, the TACT technique has received more attention as an effective method for achieving a target completion date by securing the continuous works. Although the TACT technique can maintain a steady flow without the interruption of works in order to utilize the resources of the repetitive works, it can not be considered as the systematic scheduling technique because the schedule computations are not possible as well as a critical path can not be recognized. This paper proposes the applicabilities of scheduling and monitoring the TACT schedule by the BDM technique as comparing and analyzing the methodologies for apartment finish works by the Excel, the Primavera(P6) based on the PDM technique, and the Beeliner based on the BDM technique that is a new networking technique, respectively.
\end{abstract}

Keyword : CPM, TACT, PDM, BDM, Apartment Finish Works

\section{1. 서 론}

\section{1 연구의 배경 및 목적}

현대의 건설사업 환경은 건축, 토목, 기계, 전기, 조경 등 의 모든 분야를 포함하는 복합 건설사업으로 추진되고 있 고 대형화, 고층화 되어감에 따라 반복공정이 증가하게 되 면서 작업 연속성 확보를 통한 목표공기를 달성하는 TACT 공정관리기법이 대두되고 있다.

고층건물과 공동주택 등의 유사한 평면을 가지는 층 또는 동일한 작업내용을 가진 작업들은 서로 상호 연관성을 가 지게 되고, 선행작업의 지연 또는 단위시간당 작업량의 변 화에 따라 후속적인 대기나 작업간의 간섭을 발생시켜 비 용증가와 공기지연과 같은 비생산적인 행위를 초래한다 (Sang-Jun Park 2006). 따라서 반복작업의 자원을 효율적으 로 활용하기 위해 작업과 작업이 단절되지 않도록 일정한 작업흐름을 유지할 수 있는 $\mathrm{TACT}$ 공정관리기법에 관심이 주목되고 있지만 CPM기법에 의해 수립된 네트워크가 아니 기 때문에 전진계산, 후진계산, 주공정(critical path) 관리,

\footnotetext{
* Corresponding author: Yoo, Jaewoo, Department of Architectural Engineering, Kangwon University, Chuncheon, Korea

E-mail: lastsupper87@gmail.com

Received June 3, 2013: revised August 1, 2013

accepted August 8, 2013
}

여유시간을 알 수 없어 체계적인 공정관리라 할 수 없다. 공정관리는 해당 사업에 적합한 공정관리기법을 선택하고 그에 맞는 공정관리 소프트웨어를 통해 체계적으로 수행되 어야 하지만 TACT기법은 단지 엑셀(Excel) 프로그램으로 표현하는 시각적인 측면만 강조할 뿐 작업간 관계(Relation) 을 표현할 수 없기 때문에 정상적인 공정관리기법이라 할 수 없다.

본 연구에서는 공동주택의 마감공사 $\mathrm{TACT}$ 공정계획을 정상적인 공정관리로 전환시키기 위해 기존의 엑셀, 그리고 현재 가장 보편적으로 적용되고 있는 $\mathrm{PDM}$ 기법 기반의 공 정관리소프트웨어인 Primavera(P6), 2010년 제안된 새로운 공정관리기법인 BDM기법(Seon-Gyoo Kim 2010) 기반의 공 정관리소프트웨어인 Beeliner(Seon-Gyoo Kim 2013)로 작성 되고 운영하는 $\mathrm{TACT}$ 공정계획들을 비교 분석함으로써, $\mathrm{BDM}$ 기법에 의한 $\mathrm{TACT}$ 공정계획 수립 및 운영상 적용성 을 제시하고자 한다.

\section{2 연구의 범위 및 방법}

본 연구는 $\mathrm{TACT}$ 공정계획의 대상을 공동주택의 마감공 사로 하며, 다음과 같이 연구를 진행하였다.

첫째, $\mathrm{TACT}$ 기법과 $\mathrm{BDM}$ 기법에 대해 이론적으로 고찰한 다.

둘째, 엑셀에 의해 수작업으로 작성된 $\mathrm{TACT}$ 공정계획의 한계 및 제한사항을 분석한다. 
셋째, $\mathrm{PDM}, \mathrm{BDM}$ 기법 기반의 공정관리소프트웨어에 의 해 작성된 $\mathrm{TACT}$ 공정계획 표현 방법 및 사례를 제시한다. 넷째, 엑셀, $\mathrm{PDM}, \mathrm{BDM}$ 기법에 의한 $\mathrm{TACT}$ 공정계획 작 성 및 운영 방법을 비교분석하고, $\mathrm{BDM}$ 기법의 적용성을 제 시한다.

\section{TACT 및 $\mathrm{BDM}$ 기법 이론적 고찰}

\subsection{TACT기법 이론적 고찰}

\subsubsection{TACT기법의 기본 개념}

$\mathrm{TACT}$ 는 사전적으로 측정할 수 있는 단위를 의미하며 규 칙적으로 분할된 시간 구분, 박자라는 뜻의 단어로 $\mathrm{TACT}$ 공정관리는 작업구역을 일정하게 분할하고 작업시간을 일 정하게 통일시켜, 이른바 동기화를 통하여 공종간 대기시간 없는 연속작업을 가능케 하여 선·후행 작업의 흐름을 연속 적으로 만드는 개념이다.

\section{Table 1. TACT Scheduling Technique}

\begin{tabular}{c|l|l}
\hline \multirow{2}{*}{ Definition } & $\begin{array}{l}\text { Scheduling technique that makes work-flow between consecutive } \\
\text { activities continuously by unifying work spaces constantly }\end{array}$ \\
\hline \multirow{3}{*}{ Purpose } & $\begin{array}{l}\text { Resource leveling by in-time \& just-quantity } \\
\text { Time shortening by "Zero" of waiting time between works } \\
- \text { Quality improvement by standardization of works }\end{array}$ \\
\hline \multirow{3}{*}{ Background } & Systematic & Improvement of worker's productivity \\
\cline { 2 - 3 } & Technical & $\begin{array}{l}\text { Effective management resource allocation of } \\
\text { repetitive works }\end{array}$ \\
\hline
\end{tabular}

\subsubsection{TACT기법의 특징}

$\mathrm{TACT}$ 공정관리는 작업을 층별, 공종별로 세분화하여 각 작업(activity) 기간이 같아지도록 인원, 장비를 배치(동기화) 하는 방식으로 같은 층 내 작업들의 선, 후행 관계를 조정 한 후 층별 작업이 순차적으로 진행될 수 있도록 계획하며 모든 공정이 동일한 시간(6일)내에 처리될 수 있도록 작업 량과 인원, 공종을 분할하는 것이 필수적이다.

연속·반복적인 공정관리에 의한 공사기간 단축과 공사비 절감에 효과적이며 $\mathrm{TACT}$ 기법의 목표인 작업 연속성 확보 및 자원 평준화 달성에 따라 공종간 간섭현상의 발생빈도 가 높고 반복작업 관리가 중요한 마감공사 부분에서 많이 적용되고 있는 실정이다. 따라서 여러 $\mathrm{TACT}$ 공정관리 종 류에 따른 적정 TACT 시간(time) 산출에 대한 연구가 계속 되고 있다.

$\mathrm{TACT}$ 공정관리는 3 가지의 관리 포인트가 있다. 첫째로 협력업체의 의견을 반영함으로써 협력업체의 노하우를 활 용하고 일방적인 공정진행이 아닌 협의와 자율에 의한 공 정관리가 될 수 있도록 하며, 둘째로 $\mathrm{TACT}$ 공정관리 실행 을 위한 전제 조건은 사전 계획 완비이기 때문에 이를 위
한 철저한 시공계획을 해야 한다. 마지막으로 선행공정은 후행공정에 피해가 없도록 합의사항 및 일정을 준수하여야 만 하고 이를 위해서는 지속적인 점검과 협의가 이루어져 야 한다.

\subsubsection{TACT기법 적용 기준 및 실제 시례}

$\mathrm{TACT}$ 기법을 공동주택 마감공사에 적용하기 위한 주요 기준은 다음과 같이 다섯 가지로 구성된다(Fig. 1).

첫째, 골조공사의 한개 층 사이클(Cycle)은 6일을 기준 한 다. 6일 공정을 확보하기 위하여 간절기에 고강도 콘크리트 및 조강제를 적용, 동절기에는 가열보양을 통해 초기강도를 확보해야 한다.

둘째, $\mathrm{TACT}$ 기간은 골조 사이클과 같이 6일로 적용하여 동기화 한다.

셋째, 마감공사의 조기착수를 위해 골조공사 4 층 완료시 착수한다.

넷째, 마감의 단위 층은 1 개 층 단위로 한다.

다섯째, 기포/바닥미장은 작업량의 확보를 위해 2 개 층 단위로 마감한다.

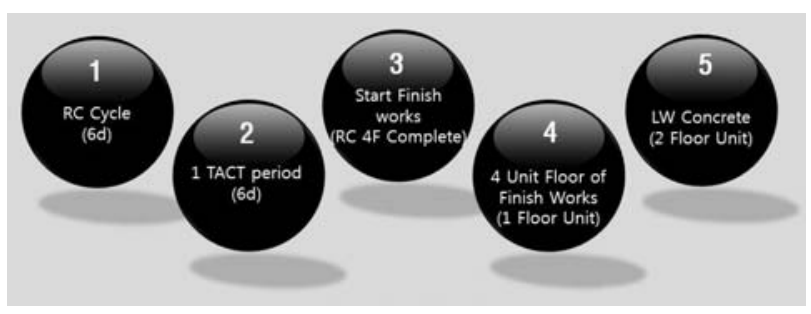

Fig. 1. Major Five Applied Techniques

$\mathrm{TACT}$ 기법 실제 적용사례는 $\mathrm{D}$ 건설이 공동주택 마감공사 에 적용하는 것으로서, $\mathrm{TACT}$ 의 마감공종은 총 19 개로 구 성되는데 1 8번은 습식마감 공종으로 66일 소요, 9 14번은 건식마감공종으로 42일 소요, 15 19번은 최종마감이며 전층 단위 관리로 21 일 소요되어 총 129 일의 마감기간을 갖게 된다. 각 공종의 $\mathrm{TACT}$ 는 1 번부터 19번까지 순차적으로 이 루어지며 골조공사와 같은 기울기에 동일 기간으로 진행된 다(Fig. 2).

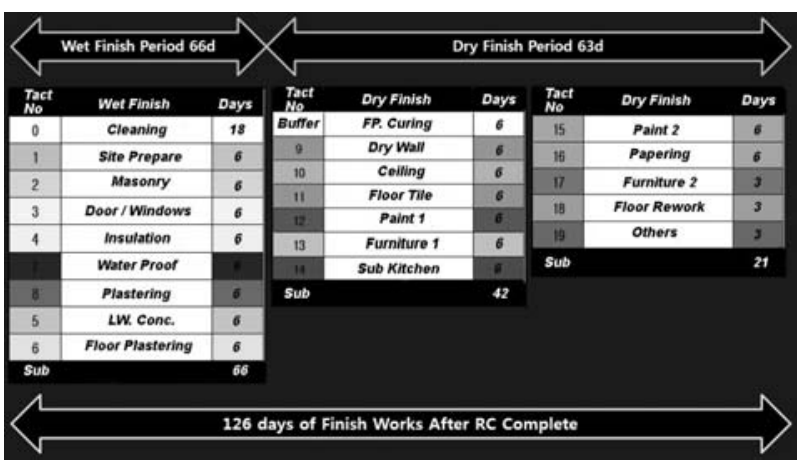

Fig. 2. TACT Classification 
건설현장에서 TACT 공정계획은 대부분 엑셀(Excel)을 활 용하여 수작업으로 작성되고 있다. Fig. 3은 엑셀로 작성된 $\mathrm{TACT}$ 공정계획의 예를 보여주고 있는데, Fig. 2에서 정의 된 19 종류의 단위 $\mathrm{TACT}$ 들이 색을 달리하며 저층에서 상 층으로 연속하여 올라가는 형태, 선·후행 $\mathrm{TACT}$ 간 연결관계 는 수평방향으로 나열되고 있는 형태를 보여주고 있다.

이와 같이 수작업에 의해 $\mathrm{TACT}$ 공정계획을 수립할 경우, 운영단계에서 특정 단위 TACT가 예측하지 못했던 돌발 상 황에 의해 지연되거나 또는 단축되었을 경우, 후속 단위 $\mathrm{TACT}$ 의 위치를 모두 수작업으로 변경시켜야 하는 불편함 이 발생하는 동시에, 선행 $\mathrm{TACT}$ 의 변화에 따른 후행 $\mathrm{TACT}$ 들의 영향을 논리적으로 신속 정확하게 예측하는 것 은 매우 어렵다.

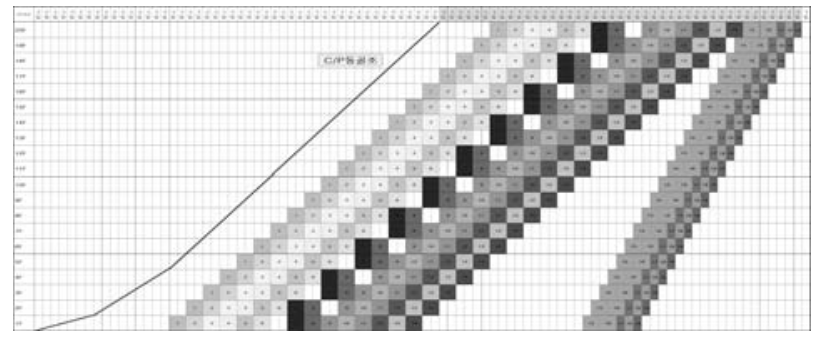

Fig. 3. TACT Schedule by Excel

\subsection{4 공정관리기법으로서의 TACT기법 한계 및 문제점}

$\mathrm{TACT}$ 기법은 일정한 TACT Time(작업소요기간, 혹은 작업개시부터 다음 공구에 이동할 때까지의 시간간격 (Kyung-Suk Kim 2002)에 따라 단위 TACT간의 연계관계를 쉽게 알 수 있으며, LOB(Line of Balance) 공정표현의 경우 기울기에 따른 작업속도를 쉽게 파악할 수 있는 등 공정 흐름의 시각적 표현이 매우 훌륭하다. 또한 공기단축, 정해 진 시간 및 정량생산, 시공에 의한 자원 평준화와 공정간 보유시간을 "Zero"로 하여 공기 단축 및 품질 향상이 가능 하기 때문에 관심이 모아지고 있다.

그러나 건설 사업에서 공정관리는 전체 공정현황 파악, 여유시간 계산, 계획 대비 실행의 원인 분석, 반복 작업의 공정관리, 대기시간 단축, 공종간섭의 분석 등의 문제를 관 리할 수 있는 체계적인 공정관리 기법 적용이 요구되고 있 는데, 이러한 측면에서 $\mathrm{TACT}$ 기법은 한계를 가지고 있다.

정상적인 공정관리기법으로서의 $\mathrm{TACT}$ 기법의 한계는 크 게 세 가지로 나누어진다. 첫째는 TACT기법이 CPM 네트 워크 방식의 공정관리 기법이 아니라는 점이다. 공정관리를 위해서는 정확한 논리(logic)을 형성해 공정표를 작성하고 각 작업의 착수시점과 종료시점, 작업이 보유하고 있는 여 유시간을 수학적으로 계산하여 전체 공정계획을 논리적으 로 표현할 수 있어야 한다. 만약 전체 공정계획이 논리적으 로 표현되지 못한다면 각 작업의 착수 및 종료시점, 여유시 간을 파악할 수 없기 때문에 전체 공정계획의 핵심 공정선
인 $\mathrm{CP}$ (Critical Path)를 관리 할 수 없게 되므로 공정관리의 체계적이며 효율적으로 수행할 수 없게 된다. 즉 TACT기 법은 그림 3과 같이 단순히 엑셀에 의한 단위 $\mathrm{TACT}$ 의 시 각적 연관관계만을 파악할 수 있을 뿐 각 단위 $\mathrm{TACT}$ 의 착 수 및 종료시점, 여유시간, $\mathrm{CP}$ 여부 등을 파악할 수 없게 된다.

둘째, TACT 공정표상의 실적관리에 관한 사항이다. 실제 공사가 진행되면서 계획과 실행의 완벽한 일치는 거의 불 가능하다. 지연 원인을 분석하여 시공계획을 철저히 세우고 사전 공기지연을 초래할 수 있는 요인을 발굴하여 미리 대 처한다고 해도 건설현장은 비반복 작업의 연속, 무형에서 유형의 결과를 산출하는 특수성으로 인해 예상치 못한 일 들이 무한히 발생하므로 계획 대비 실적의 비교 분석은 필 수적이다. 실제 작업(activity)별 실적 공정진도를 표현할 때 공정표 상의 각 작업의 계획공정 아래부분에 실적을 입력 하여 계획공정과 실적을 비교하지만 TACT공정계획은 가로 로 단위 $\mathrm{TACT}$ 들이 바로 붙어 표현되기 때문에, 계획공정 과 $100 \%$ 일치 할 수 없는 현장에서는 계획보다 앞서거나 뒤처지는 실적부분에서 전·후 $\mathrm{TACT}$ 의 실적들이 겹치거나 중복되어 나타나므로 실적 공정진도를 정확히 파악할 수 없는 문제가 발생한다.

셋째, 계획 대비 실적의 원인분석 관련 사항이다. 일정 시 점을 기준으로 계획보다 실적이 빨리 진행되거나 늦어지는 경우 원인을 분석해 계획 공기를 준수하기 위한 해결책을 수립하여야 하지만, $\mathrm{TACT}$ 기법은 계획 대비 실적의 비교분 석 이 불가능하여 계획 공기를 준수하기 위한 최적의 만회 공정계획을 수립하는데 한계가 있다.

이상과 같이 $\mathrm{TACT}$ 기법은 공정관리기법으로 문제점 및 한계를 가지고 있으므로, 이를 극복하기 위한 새로운 방법 을 모색할 필요가 있다.

\section{$2.2 \mathrm{BDM}$ 기법 이론적 고찰}

\subsubsection{BDM 기법의 기본 개념}

$\mathrm{CPM}$ 네트워크 기법 중 $\mathrm{PDM}$ 기법의 중복관계 표시의 비효 율성과 한계를 극복하기 위해 새롭게 재안된 $\mathrm{BDM}$ (Beeline Diagramming Method)기법은 선·후행 작업 간 연결관계를 선행작업 중간 임의의 시점에서 후행작업 중간 임의의 시 점으로 최단거리의 직선으로 표현하는 것이다(Fig. 4).

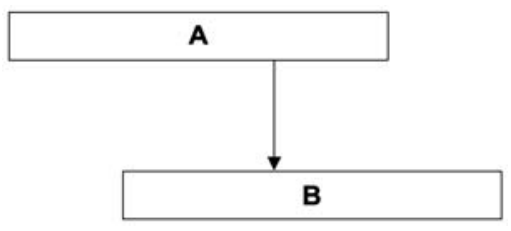

Fig. 4. Basic Concept of BDM Technique 
이 $\mathrm{BDM}$ 기법은 선·후행 작업 중간 어느 시점에서도 직접 연결하기 때문에 선·후행 작업 간 중복관계 표시가 단순화 되며, 선·후행 작업 간 다중 연계를 가능하게 함으로써 작 업기간이 길고 다중의 중간 완료시점을 갖는 선·후행 작업 간 복수의 연계관계 표시가 가능하다.

\subsubsection{BDM기법의 선 · 후행 표시방법}

$\mathrm{BDM}$ 기법에서 선 - 후행 표시방법은 세 가지로 구분하는 데, 첫째, 선행작업과 후행작업 중복관계를 각각의 작업들 이 착수 후 진행된 경과일수를 Fig. 5와 같이 'N-N'으로 표 시하는 방법이다.

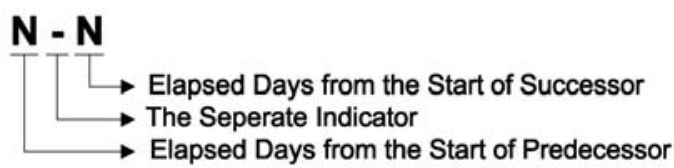

Fig. 5. Representation Type by the Elapsed Days

선행되는 ' $\mathrm{N}$ '은 선행작업이 착수 한 후에 경과일수를 표 시하고, 후행되는 ' $\mathrm{N}$ 은 후행작업이 착수 한 후에 경과일수 를 표시한다. 중간의 ' - 은 선·후행 작업의 경과일수 ${ }^{\prime} \mathrm{N}$ 을 분리하는 표시자(indicator)로 표시하는 방법이다.

둘째, 선행작업과 후행작업이 착수 후 진행된 경과비율을 표시하는 방법이다.

\section{$\mathbf{N} \% \mathbf{N}$ \\ $\rightarrow$ Elapsed Percentages from the Start of Successor \\ The Seperate Indicator of Percentage Relationship \\ Elapsed Percentages from the Start of Predecessor}

Fig. 6. Representation Type by the Elapsed Percentage

Fig. 6 에서 앞의 ' $\mathrm{N}$ 은 선행작업이 착수 후 진행된 경과비 율을 표시하고, 뒤의 ' $N$ 은 후행작업이 착수 후 진행된 경 과비율을 표시한 것이다. 중간의 ‘\%는 선·후행 작업의 경 과 퍼센트 ${ }^{\prime} \mathrm{N}$ 을 분리하는 표시자로 선·후행 작업이 일정 비율 경과된 후 연계된다는 의미를 함축하고 있다.

셋째, 선행작업 완료 후 일정기간이 지난 후 후행작업이 착수되는 경우로서 ' $<\mathrm{N}>$ '의 형식으로 Fig. 6 과 같이 표시하 는 방법이다.

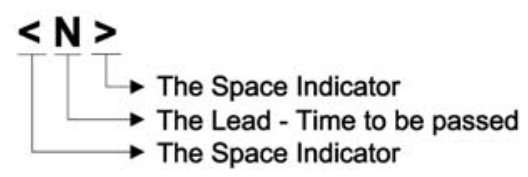

Fig. 7. Representation Type by the Lead-Time
Fig. 7에서 중간의 ' $\mathrm{N}$ 은 선행작업 종료 후 후행작업이 착 수되기 전 일정기간인 Lead-Time을 표시한 것이고, 숫자 $\mathrm{N}$ 의 앞 '<'와 '>'는 Lead-Time을 입력하는 공간표시자이다.

만약 선행 작업의 복수의 완료시점들과 후행 작업의 복수 의 완료시점들 간에 양방향 복수의 Beeline을 갖고 있는 경 우 이를 정확하게 표현할 수 있다. Fig. 8과 같이 선행작업 과 후행작업간 양방향 복수의 완료시점을 갖는 경우, 선행 작업에서 후행작업간 연결지점을 최단거리로 연결하여 복 수의 완료시점을 표현할 수 있다(Seon-Gyoo Kim 2012).

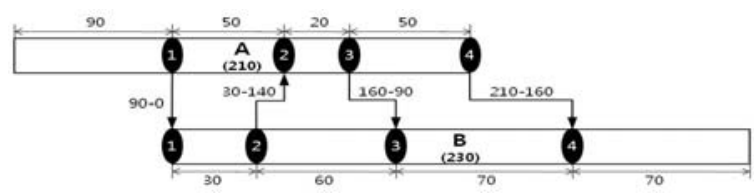

Fig. 8. Example of Multiple Overlapping Relationships

\subsection{3 $\mathrm{BDM}$ 기법의 효과}

$\mathrm{BDM}$ 기법은 일정계산과 여유시간 계산을 위한 완벽한 알 고리즘(algorithm)을 갖고 있어 새로운 개념의 공정관리기 법으로 정의된다. 그리고 $\mathrm{BDM}$ 기법은 기존의 $\mathrm{PDM}$ 기법이 갖는 작업 간 중복관계의 표시가 작업의 착수와 종료시점 에만 국한되지 않고, 작업의 중간 어느 시점에서도 상호관 계를 연결시킬 수 있을 뿐 아니라 복수의 중복관계도 표시 할 수 있다. 이러한 $\mathrm{BDM}$ 기법의 특징은 기존 공정관리기법 에 비해 정확한 공정계획 수립이 가능할 뿐만 아니라 폭넓 은 융통성 및 시각적 표현의 우수성을 제공하고 있어, 더욱 다양화 복합화 되고 있는 건설환경에서 공정관리의 효율성 을 향상시키는 동시에 공정관리의 발전에도 크게 기여할 것으로 기대된다.

\section{3. 공정관리 소표트웨어에 의한 TACT 공정계획 수립}

\subsection{Primavera(P6)에 의한 TACT 공정계획}

\subsubsection{Primavera 개요}

Primavera Systems, Ins는 1986년 Joel Koppelman이라는 토목기술자에 의해 미국에서 설립되었다. 당시 판매되었던 첫 제품인 Primavera Project Planner는 앞 이니셜만을 따 서 P3라고 부르게 되었다. 기존의 P3가 가지고 있던 Data File Server 개념에서 타 시스템과의 연동을 위해 관계형 데이터베이스를 사용하는 Primavera Enterprise 1.0 버전을 2000 년에 출시하게 되었으며, 6.0 버전이 출시된 후 제품명 을 Primavera P6로 변경하였다.

Primavera P6에 적용되는 공정관리기법은 PDM(Precedence Diagramming Method)기법이다. PDM기법은 1956년 최초로 
제안된 $\mathrm{CPM}$ 공정괸리기법인 $\mathrm{ADM}$ (Arrow Diagramming Method)기법에서 표현하지 못하는 작업 간 중복관계 표현 을 가능하게 함으로써 작업간 논리를 실제와 동일하게 표 현할 수 있다는 장점을 가지고 있으나, 공정계획의 시각적 표현상 문제점을 가지고 있다(Seon-Gyoo Kim 2010).

\subsubsection{P6에 의한 TACT 공정계획 수립}

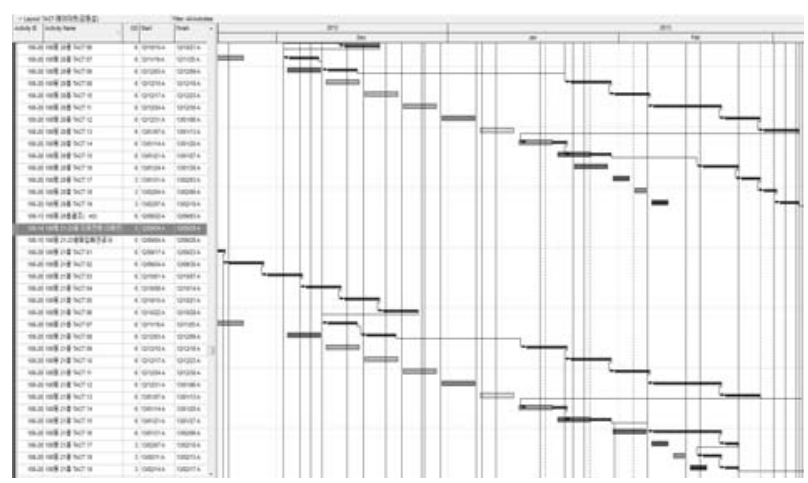

Fig. 9. Example of Lowest Level's TACT Schedule by P6

Fig. 9는 P6로 작성된 최하위 레벨(Level)의 TACT 공정계 획 예를 보여주고 있다. $\mathrm{P} 6$ 에서 공정표의 표현은 한 줄 (row)에 하나의 작업만을 표현하는 바차트(bar chart) 형식 이며 바(bar)로 표현된 작업간 연결관계는 $\mathrm{FS}, \mathrm{SS}, \mathrm{FF}, \mathrm{SF}$ 형태로 표현한다. P6는 단위 TACT들을 한 줄에 하나씩 표 현하므로 만약 20 층 규모의 아파트 마감공사가 19 종류의 $\mathrm{TACT}$ 로 구성된다면 전체 $\mathrm{TACT}$ 의 수는 380 개가 되므로 총 380줄(row)이 필요하게 된다. 더욱이 층수가 증가된다면 P6로 표현된 TACT 공정표는 파피루스(papyrus)처럼 수직 아랫방향으로 한없이 늘어나게 된다. 시간 축과 직각인 수 직방향으로 한없이 나열된 전체 공정계획을 한 눈에 파악하 기란 거의 불가능하며 이러한 시각적 표현상의 불편함이 $\mathrm{PDM}$ 기법을 채택한 $\mathrm{P} 6$ 의 최대 약점이라 할 수 있을 것이다.

또한 Fig. 9에서 단위 TACT의 실제착수일(actual start)과 실제완료일(actual finish)을 계획 바와 비교하여 보여주지 않고 있어, 단위 TACT가 계획 대비 빠른지 또는 늦는지 시각적으로 정확하게 파악하는 것도 매우 어렵다.
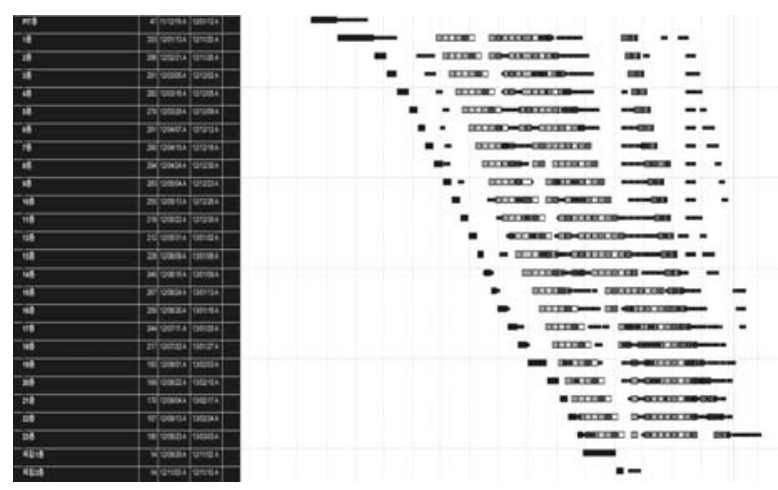

Fig. 10. TACT Schedule summarized to Upper Level by P6
Fig. 10은 P6에서 최하위 레벨의 단위 TACT를 상위 레벨 로 요약한 형태를 보여주고 있다. 요약된 $\mathrm{TACT}$ 공정계획 은 한 줄에 복수의 요약 $\mathrm{TACT}$ 를 나타내고 있어, Fig. 3의 엑셀로 작성된 $\mathrm{TACT}$ 공정계획과 유사한 형태이다. 그러나 Fig. 3에서는 층수가 아래에서 위로 증가하는 계단식 모습 이지만, Fig. 10은 층수가 위에서 아래로 증가되고 있어 역 계단식의 $\mathrm{TACT}$ 공정표로 표현되는 것을 알 수 있다. 더욱 이 Fig. 10에서는 요약된 TACT간 연결관계를 표시하지 않 고 있으며, 요약된 $\mathrm{TACT}$ 공정계획에서 실적표시는 아예 표현되지 않고 있다.

이상과 같이 $\mathrm{P} 6$ 로 작성된 $\mathrm{TACT}$ 공정계획은 시각적 표현 상 많은 문제점을 내포하고 있어 실제 건설현장에서 실무 자들이 실제 공정관리에 적용하는데 한계가 있다. 따라서 건설현장 실무자들에게 좀 더 친근한 즉 엑셀 형식의 $\mathrm{TACT}$ 공정계획의 형식을 나타내면서도, 실적(actual)을 동 시에 표현할 수 있으며 선행 $\mathrm{TACT}$ 의 변화에 후행 $\mathrm{TACT}$ 들이 어떠한 영향을 받게 되는지 논리적으로 신속 정확하 게 파악할 수 있는 CPM 공정관리기법이 완벽하게 적용되 는 새로운 $\mathrm{TACT}$ 공정계획 작성방법을 모색할 필요가 있다.

\subsection{Beeliner에 의한 TACT 공정계획}

\subsubsection{Beeliner 개요}

Beeliner는 $\mathrm{BDM}$ 기법을 기반으로 개발된 새로운 개념의 공정관리 프로그램으로 기존의 $\mathrm{PDM}$ 기법을 기반으로 만들 어진 프로그램과 완전히 다른 개념의 공정관리 소프트웨어 이다. 따라서 Beeliner는 기존의 공정관리 소프트웨어와는 차별화되는 매우 독특한 특징들을 가지고 있는데, 그러한 특징들을 요약하면 다음과 같다.

첫째, 작업들에 대한 상세정보가 있는 그리드(grid) 부분 과 차트(chart) 부분을 두 개의 모니터로 나누어 작업이 가 능하다. 기존의 PDM기법 기반 소프트웨어는 그리드와 차 트가 1:1로 연결되어 있어 그리드와 차트의 분리가 불가능 하다. 그러나 Beeliner는 $\mathrm{BDM}$ 기법을 기반으로 개발되었기 때문에 그리드와 차트를 완벽하게 분리함으로써 그리드의 모든 컬럼(column)과 전체 차트를 동시에 확인하면서 작업 이 가능하다.

둘째, WBS내 모든 레벨에서 동일한 공정관리 기법으로 표현이 가능하다. 기존의 공정표는 최하위 레벨에서 공정요 약(Sum-up)을 했을 시에 서로 다른 공정관리 기법으로 표 현하게 된다. 그 과정에서 공정표의 오류가 생기거나 임의 적인 조작이 가능하다. 하지만 Beeliner는 소프트웨어 상에 서 공정요약이 가능하며, 동일한 공정관리 기법으로 표현되 기 때문에 오류 및 조작 가능성이 존재하지 않는다.

셋째, $\mathrm{ADM}$ 기법의 장점인 전체 공정을 한 눈에 파악할 수 있다는 것과 $\mathrm{PDM}$ 기법의 중복관계를 동시에 표현할 수 있다. 기존의 공정관리 소프트웨어는 대부분 $\mathrm{PDM}$ 기법을 
기반으로 만들어졌기 때문에 하나의 작업이 한 줄에 표현 되어 작업의 숫자만큼 차트가 수직 아랫방향으로 한없이 늘어났지만, Beeliner는 $\mathrm{ADM}$ 기법으로 표현된 공정표처럼 한 줄에 복수의 작업 표현이 가능하므로 전체 공정을 한 눈에 파악할 수 있도록 하는 동시에 모든 작업들간 연결관 계를 $\mathrm{PDM}$ 기법과 같은 중복관계 뿐만 아니라 양방향 다중 중복관계(Two-Way Multiple Overlapping) 표현도 가능하 다(Seon-Gyoo Kim 2012).

넷째, 실적입력일(Data Date)을 기준으로 작업이 완료된 영역과 작업이 완료되지 않은 영역을 명확하게 구분한다. 작업별 실제 진도에 따라 실적입력기준선(data date line)은 지그재그(zig-zag) 형태로 표현되며, 실적입력기준선의 좌측 은 완료되거나 진행 중인 작업들의 영역으로 색으로 채우 고, 우측은 완료되지 않은 작업들의 영역으로 무색으로 표 현한다. 이렇게 작업이 완료된 영역과 작업이 완료되지 않 은 영역을 분명하게 표시함으로서 전체 공정현황을 시각적 으로 명확하게 파악할 수 있도록 한다.

다섯째, 공정비교(schedule comparison)와 진도율정렬 (progress override) 가능을 독립적으로 또는 동시에 실행할 수 있도록 한다. 공정비교를 통해 목표공정 대비 현재공정 과의 차이 파악, 진도율정렬을 통해 계획공정을 실제공정과 일치시킴으로서 목표로 하는 계획준공일 대비 진도율정렬 에 의해 예측된 준공일이 어떻게 차이가 나는지 파악할 수 있도록 한다. 또한 공정비교와 진도율정렬을 동시에 실행시 킴으로써 계획공정 대비 실적공정 현황의 변화를 시각적으 로 명확하게 파악할 수 있도록 해준다.

\subsubsection{Beeliner에 의한 TACT 공정계획 수립}

$\mathrm{BDM}$ 기법은 $\mathrm{PDM}$ 기법과 달리 한 줄에 복수의 작업 표현 이 가능하므로 $\mathrm{TACT}$ 공정계획을 정확하게 표현할 수 있다. 본 연구에서는 $\mathrm{BDM}$ 기법으로 $\mathrm{TACT}$ 공정계획을 표현하는 두 가지 방법을 제안한다.

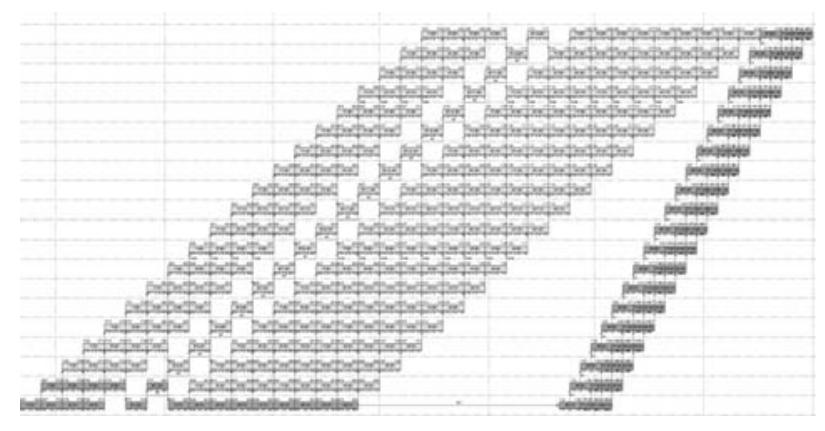

Fig. 11. Horizontal Arrangement of TACT Units

첫째, Fig. 3과 같이 엑셀로 표현된 $\mathrm{TACT}$ 공정계획과 동 일한 형식으로, 단위 $\mathrm{TACT}$ 를 가로방향으로 나열하여 표현
하는 방법이다. Fig. 11은 엑셀로 표현한 Fig. 3의 TACT공 정계획을 $\mathrm{BDM}$ 기법을 기반으로 개발된 공정관리 프로그램 인 Beeliner를 통해 표현한 것이다. Fig. 11은 Fig. 3과 매우 유사하여 $\mathrm{TACT}$ 를 실제 운영해본 현장실무자들에게는 매우 익숙한 시각적 표현형식이라는 장점을 가지고 있다. 다만 Fig. 3과 Fig. 11의 차이점은 Fig. 3은 층간 단위 $\mathrm{TACT}$ 사 이에 여유가 전혀 없으나, Fig. 11의 Beeliner에 의해 표현 된 층간 단위 $\mathrm{TACT}$ 사이에 여유 줄(row)이 존재한다는 점 이다. 이러한 차이는 Fig. 3의 표현은 단순히 계획만을 표 현하는데 비해 Beeliner는 계획 바 하부에 실적입력을 고려 하기 때문이다. 그러나 Fig. 11의 공정표에서는 단위 TACT 들이 가로로 바로 붙어있는 때문에 실적을 입력하는 경우 실적들이 중복되어 실적을 명확하게 구분할 수 없는 문제 가 발생할 수 있다.

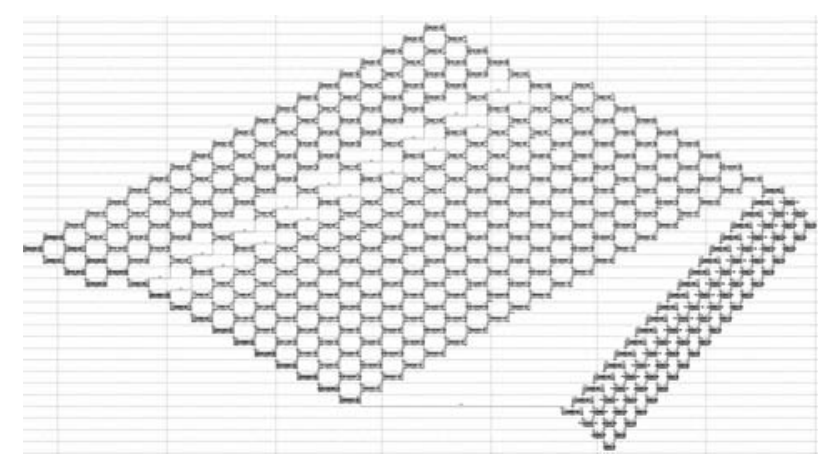

Fig. 12. Diamond Arrangement of TACT Units

둘째, 단위 $\mathrm{TACT}$ 의 계획 하단에 실적을 입력하고 이들이 중복되지 않기 위해 단위 $\mathrm{TACT}$ 들을 다이아몬드(diamond) 형식으로 Fig. 12와 같이 표현하는 방법이다. Fig. 10과 같 은 형태로 표현하면 단위 $\mathrm{TACT}$ 들에 실적을 표현할 경우 선·후행 작업들의 실적 바(bar)가 서로 중복되지 않기 때문 에 단위 $\mathrm{TACT}$ 별 계획 대비 실적 비교가 시각적으로 완벽 하게 표현될 수 있는 장점을 가지고 있다. 다만 다이아몬드 형식의 $\mathrm{TACT}$ 표현은 Fig. 3 의 엑셀로 표현한 가로방향의 $\mathrm{TACT}$ 표현과 시각적으로 차이가 있어 현장실무자들에게 익숙하지 않다는 점이다.

이상의 두 가지 방법 중 실제 건설사업의 $\mathrm{TACT}$ 공정계획에 첫 번째 방법을 적용하여 Beeliner에 의해 수립된 TACT 공정계획의 실제 예는 다음과 같다. Fig. 13은 Fig. 3의 D-TACT 공정계획에 TACT 마감공정이 착수되기 전 토공사, 기초공사, 골조공사와 $\mathrm{TACT}$ 마감공정 완료 후 준공청소, 입주준비 Activity 들을 모두 포함하는 1 개 동의 전체 공정계획을 Beeliner로 표현하고 있다. 또한 Fig. 13의 단위 TACT의 색(color)들이 Fig. 3 의 엑셀로 표현한 단위 $\mathrm{TACT}$ 의 색들과 동일하게 표현되고 있다. 


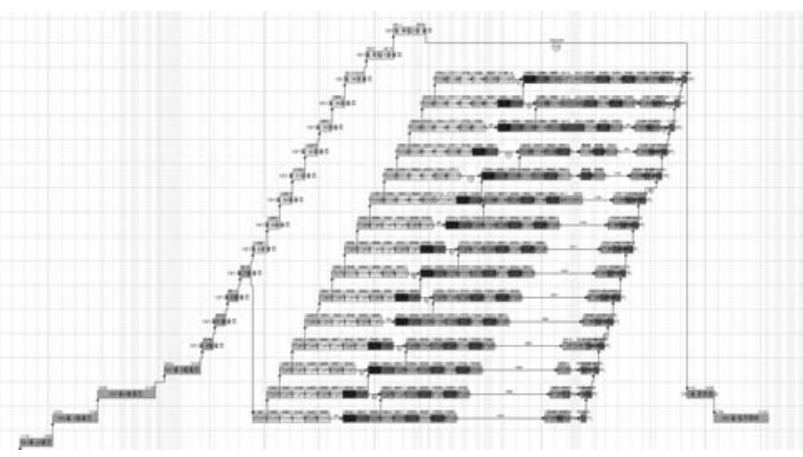

Fig. 13. BDM Schedule of Bomundong Redevelopment Apartment

Fig. 13 의 $\mathrm{BDM}$ 공정계획은 일정계산을 통해 각 작업별 착수 및 종료일, 여유시간을 산출할 수 있으므로 Critical Path 확인 및 관리가 가능하다. 또한 각 작업별 실적입력이 가능하므로 실적에 따라 전체 공정계획의 변화를 정확하게 판단할 수 있을 뿐만 아니라, 효율적인 만회 공정계획 수립 을 가능하게 하는 완전한 CPM 공정계획으로 표현되고 있 음을 확인할 수 있다.

\subsubsection{Beeliner에 의한 TACT 공정계획 운영}

현재 엑셀로 작성된 $\mathrm{TACT}$ 공정계획에서 실적입력을 하 는 사례는 거의 없으며, 대부분의 경우 TACT 공정계획만 을 참고할 뿐이다. 그러나 공정계획이란 실제 운영을 통해 계획 대비 실적현황을 비교분석하며, 필요할 경우 계획을 수정하거나 실제 작업의 속도를 조정할 때 공정관리를 제 대로 수행한다고 할 수 있을 것이다. 따라서 공정계획의 운 영측면이 배제된 엑셀기준의 $\mathrm{TACT}$ 공정관리는 정상적인 공정관리라 할 수 없다. 반면에 공정관리소프트웨어인 P6나 Beeliner는 $\mathrm{TACT}$ 단위에서 실적입력이 가능하며, 실적입력 과 동시에 차트부분에 자동으로 실적현황이 나타난다.

본 논문에서는 P6의 경우 실적입력 및 실적현황 표현방 식에 대해 보편적으로 인지하고 있는 것으로 전제하고, 새 로운 공정관리소프트웨어인 Beeliner의 $\mathrm{TACT}$ 공정계획 운 영과 관련된 실제 사례만을 기술하고자 한다.

Beeliner에서 실적현황을 입력하기 위해서는 가장 먼저 실적입력일(data date)을 지정해야 되며, 실적입력일을 지정 하면 차트화면에 실적입력일 기준선(data date line)이 수직 으로 나타난다. 실적입력일 기준선의 좌측 영역은 작업이 완료된 영역으로 노란색으로 채워지며, 우측 영역은 작업이 미완료된 영역으로 색으로 채워지지 않는다. 그 다음 작업 별로 실적을 입력하면 계획 바 바로 아래에 실적 바가 표 현되는데 실적 바의 착수시점은 정삼각형으로, 완료시점은 역삼각형으로 표현되며 진행중인 작업의 경우 잔여일수는 실선으로 표시된다. 작업별 실적 입력시 실적진도율이 계획 진도율보다 늦을 경우 기준선은 좌측으로 꺾여 들어간 형 태로 표현되며, 반대로 실적진도율이 계획진도율보다 빠를 경우 기준선은 우측으로 꺽여 나온 형태로 표현되므로 해
당 작업이 실적진도가 계획 대비 빠른지 늦은지를 시각적 으로 분명하게 확인할 수 있다. Fig. 14는 Fig. 13의 TACT 공정계획에 TACT 단위별로 실적을 입력한 차트화면을 보 여주고 있으며, 기준선의 좌측은 작업이 완료된 영역을 우 측은 작업이 미완료된 영역을 표시하고 있다. 계획진도율 대비 실적진도율이 빠른지 늦은지를 기준선이 꺾이는 모습 을 통해 시각적으로 분명히 확인할 수 있다.

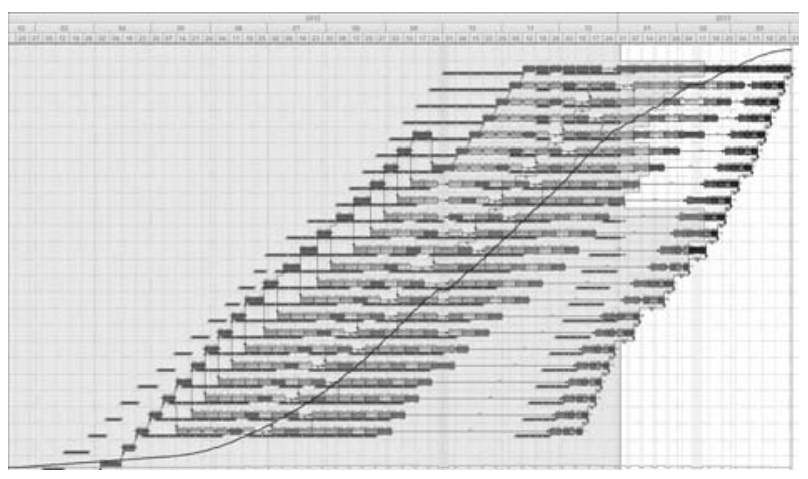

Fig. 14. Chart Screen after Actual Input of Beeliner TACT Schedule

Beeliner에서 진도율정렬 기능은 계획 대비 실적이 빠른 작업들은 좌측 방향으로 당겨지고, 반대로 계획 대비 실적 이 늦은 작업들은 우측 방향으로 밀려나면서 실적입력 기 준선이 일직선이 되도록 한다. 또한 Beeliner는 진도율정렬 과 공정비교를 동시에 보여줄 수 있는데, 실적입력 기준일 시점에서 목표공정 대비 진도율정렬을 통해 변환된 예측공 정의 차이가 빠른 경우 녹색으로 늦은 경우 적색으로 채워 서 나타내므로, 목표공정 대비 예측공정의 차이를 시각적으 로 명확하게 확인할 수 있도록 한다. Fig. 15는 실적입력 기준일 시점에서 목표공정과 진도율정렬된 예측공정의 차 이를 녹색으로 채워 보여주고 있는데 이는 목표공정 대비 실적공정이 빠르다는 것을 의미한다. 이렇게 Beeliner의 목 표공정 대비 진도율정렬된 예측공정의 차이를 명확하게 보 여주는 기능은 실적현황에 따른 공정계획의 수정 또는 작 업속도의 조절 등에 대한 의사결정을 효율적으로 지원하는 데 목적이 있다.

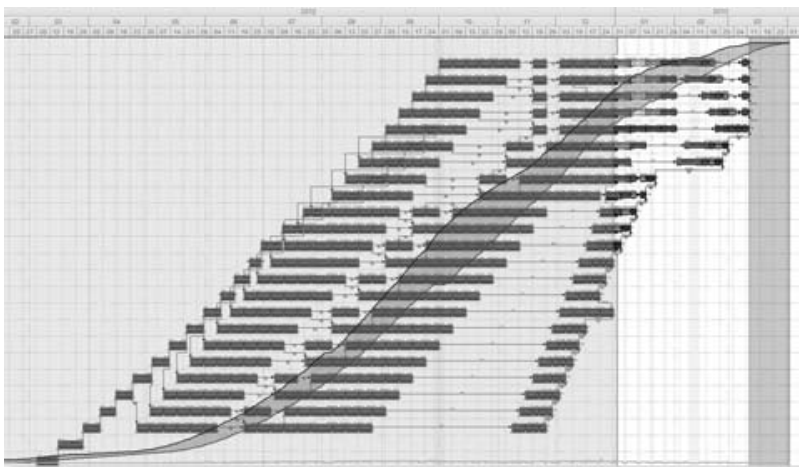

Fig. 15. Comparison of Target vs Current Schedule after Progress Override 


\section{4. 엑셀, Primavera(P6), Beeliner TACT 공정계획 비교}

본 논문에서 기술된 엑셀에 의해 작성된 $\mathrm{TACT}$ 공정계획 과 공정관리소프트웨어인 Primavera(P6)와 Beeliner에 의해 작성된 $\mathrm{TACT}$ 공정계획을 주요 항목별로 비교하면 Table 2 와 같으며, 이를 상세히 설명하면 다음과 같다.

Table 2. Comparison of Excel, Primavera(P6), and Beeliner TACT Schedule

\begin{tabular}{c|c|c|c|c}
\hline No & Items & Excel & Primavera(P6) & Beeliner \\
\hline 1 & Logic & From left o right & $\begin{array}{c}\text { From top to } \\
\text { bottom }\end{array}$ & From left to right \\
\hline 2 & Linkage & Manual & Automatic & Automatic \\
\hline 3 & Work-flow & Upward steps & Downward steps & Upward steps \\
\hline 4 & $\begin{array}{c}\text { Schedule } \\
\text { Sum-Up }\end{array}$ & Manual & Automatic & Automatic \\
\hline 5 & $\begin{array}{c}\text { Linkage of } \\
\text { Summarized } \\
\text { Activities }\end{array}$ & Manual & Impossible & Automatic \\
\hline 6 & $\begin{array}{c}\text { Actual } \\
\text { Express }\end{array}$ & Manual & Automatic & Automatic \\
\hline 7 & $\begin{array}{c}\text { Progress } \\
\text { Override }\end{array}$ & Impossible & Automatic & Automatic \\
\hline
\end{tabular}

첫째, $\mathrm{TACT}$ 공정계획 논리(logic)의 표현이다. 엑셀로 작 성된 $\mathrm{TACT}$ 공정계획인 Fig. 3 을 살펴보면 한 줄(row)에 복 수의 단위 TACT들이 나열되고 있어 단위 층에서 공정의 논리가 시간 축과 평행인 수평방향으로 좌에서 우로 흘러 가고 있음을 확인할 수 있는데, 이렇게 공정의 흐름이 시간 축과 평행일 경우 공정의 논리를 파악하는데 매우 유리하 다. 그러나 P6로 작성된 공정계획인 Fig. 9를 살펴보면 한 줄에 하나의 단위 $\mathrm{TACT}$ 만이 나열되고 있고 단위 층에서 공정의 논리가 시간 축과 직각인 수직방향으로 위에서 아 래로 흘러가고 있음을 확인할 수 있는데, 이렇게 공정의 흐 름이 시간 축과 수직인 경우 공정의 논리를 파악하는데 매 우 불리하다. 마지막으로 Beeliner로 작성된 $\mathrm{TACT}$ 공정계 획인 Fig. 13을 살펴보면 엑셀로 작성된 형식과 동일하게 한 줄(row)에 복수의 단위 TACT들이 나열되고 있어 단위 층에서 공정의 논리가 시간 축과 평행인 수평방향으로 좌 에서 우로 흘러가고 있으므로 공정의 논리를 파악하는데 매우 유리하다.

둘째, $\mathrm{TACT}$ 공정계획 논리의 작성이다. 사무용 전문 소 프트웨어인 엑셀은 단위 $\mathrm{TACT}$ 간 논리를 수작업으로 연결 할 수밖에 없는데 반해, 공정관리 전문 소프트웨어인 $\mathrm{P} 6$ 와 Beeliner는 작업 간 논리에 해당하는 수치를 입력하면 논리 가 자동으로 연결된다.

셋째, TACT 공정계획 작업진행 방향의 표현이다. 엑셀과 Beeliner는 하층이 아래이고 상층이 위인 상향식 계단형식
으로 표현되고 있어 작업의 진행 방향과 동일하다. 반면에 P6는 Fig. 9의 최하위 공정계획에서는 단순히 하층이 위이 고 상층이 아래인 하향식으로 수직 나열하고 있으며, Fig. 10 의 요약공정에서는 하향식 계단형식으로 표현하고 있는 데 이는 작업의 진행과 정반대 방향이다.

넷째, TACT 공정계획 요약 기능이다. 공정계획은 업무분 류체계(WBS)를 기준으로 작성되므로 WBS 하위 레벨(level) 에서 상위 레벨로 요약이 되어야 한다. 엑셀로 작성된 공정 계획은 수작업으로 요약할 수밖에 없으나, P6와 Beeliner에 서는 공정계획을 WBS기준으로 하위 레벨에서 상위 레벨로 자동 요약이 가능하다.

다섯째, 요약된 공정계획에서 요약작업간 연결관계 표현 이다. 요약된 작업간 연결관계 표현은 요약 공정계획만으로 의사결정을 해야 하는 발주자를 포함하는 상위계층의 사업 책임자들에게는 전체 사업흐름과 현황을 파악하는데 매우 유용한 정보가 될 것이다. 엑셀은 수작업으로 공정계획을 요약하므로 요약작업간 연계표현도 수작업으로만 가능하다. 반면에 P6로 요약된 공정계획에서 요약작업간 연결관계 표 현은 불가능하다. 그러나 Beeliner에서는 $\mathrm{BDM}$ 기법의 양방 향 다중 중복관계 표현방식(Fig. 8)을 통해 요약된 공정계획 에서 요약작업간 복수의 연결관계를 자동으로 완벽하게 표 현할 수 있다.

여섯째, 단위 $\mathrm{TACT}$ 의 실제현황(actual status) 표현이다. 일반적으로 엑셀로 작성된 $\mathrm{TACT}$ 공정계획에서 실제현황은 표시하지 않지만, 필요하다면 수작업으로 가능하다. 그러나 P6와 Beeliner에서는 단위 TACT별 실제현황을 입력하면 차트상에 시각적으로 자동 표현되며 계획 대비 실적에 대 한 비교분석이 가능하다. P6에서는 실적입력 기준선을 톱니 형태로 표현할 수 있으나, 작업이 완료된 영역과 완료되지 않은 영역을 색채움으로 구분하지 않는다. 반면에 Beeliner 에서는 본 논문 3.2.3에서 기술한 바대로 실적입력 기준선 이 지그재그 형태로 나타나며, 작업이 완료된 영역과 완료 되지 않은 영역을 색채움으로 구분한다.

일곱째, 진도율정렬이 가능한지 여부이다. 진도율정렬의 기능 및 효과는 본 논문 3.2.3에서 기술한 바와 같으며, 엑 셀로 작성된 공정계획에서는 불가능하지만 P6와 Beeliner로 작성된 공정계획에서는 진도율정렬이 가능하다. 다만 $\mathrm{P} 6$ 는 진도율정렬을 통해 최종 준공목표일의 변화만을 확인할 수 있는 반면, Beeliner에서는 공정비교와 진도율정렬을 동시에 실행시켜 목표공정 대비 진도율정렬된 예측공정의 차이를 색채움하여 시각적으로 명확하게 보여줄 수 있다.

이상과 같은 엑셀, $\mathrm{P} 6$, Beeliner로 작성된 $\mathrm{TACT}$ 공정계획 비교를 통해, 엑셀로 작성된 $\mathrm{TACT}$ 공정계획은 시각적 표 현에서 유리한 측면을 제외하고는 정상적인 공정관리를 수 행할 수 없고, $\mathrm{P} 6$ 로 작성된 $\mathrm{TACT}$ 공정계획은 정상적인 공 정관리를 수행할 수 있으나 공정계획 및 운영상 시각적 표 
현에서 불리한 점들이 다수 존재하며, Beeliner로 작성된 공 정계획은 정상적인 공정관리 뿐 만아니라 공정계획과 운영 상 시각적 표현에서 매우 유리하다는 점을 확인할 수 있다.

\section{5. 결론}

$\mathrm{TACT}$ 공정관리기법은 최근 대형화, 고층화되어 가는 공 동주택 마감공사의 반복공정에서 작업의 연속성 확보를 통 한 목표공기를 달성하는 방법으로 많이 적용되고 있다. 그 러나 사무용 전문 소프트웨어인 엑셀에 의해 수작업으로 작성된 $\mathrm{TACT}$ 기법이 체계적인 공정관리기법으로 인정받기 에 한계가 있음은 분명하다.

본 연구에서는 $\mathrm{TACT}$ 기법을 정상적인 공정관리기법으로 전환시키기 위해, 기존의 엑셀에 의한 방법, 건설현장에서 가장 보편적으로 적용되고 있는 $\mathrm{PDM}$ 기법 기반의 공정관리 소프트웨어인 Primavera(P6)에 의한 방법, 그리고 2010년 새롭게 제안된 공정관리기법인 $\mathrm{BDM}$ 기법 기반으로 개발된 공정관리소프트웨어인 Beeliner에 의해 작성된 $\mathrm{TACT}$ 공정 계획들에 대한 사례를 제시하고 비교분석한 결과 다음과 같은 사항들이 도출되었다.

첫째, 엑셀로 작성된 $\mathrm{TACT}$ 공정계획은 시각적 표현에서 유리한 측면을 제외하고는 정상적인 공정관리를 수행할 수 없다. 둘째, $\mathrm{P} 6$ 로 작성된 $\mathrm{TACT}$ 공정계획은 정상적인 공정 관리를 수행할 수 있으나 공정계획 및 운영상 시각적 표현 에서 불리한 점들이 다수 존재한다. 셋째, Beeliner로 작성 된 공정계획은 정상적인 공정관리 뿐 만 아니라 공정계획 과 운영상 시각적 표현에서 매우 유리하다는 점을 확인하 였다.

따라서 본 연구에서 제안한 $\mathrm{BDM}$ 기법으로 수립 및 운영 되는 TACT 공정계획은 TACT 기법을 통해 이루고자 하는 원래의 목적을 충분히 만족시키는 동시에 $\mathrm{TACT}$ 기법을 정 상적인 공정관리기법으로 인정받을 수 있도록 함으로써, $\mathrm{TACT}$ 기법이 건설사업에 더욱 적극적이며 효율적으로 적 용할 수 있도록 하면서 향후 공정관리의 발전에도 일조할 수 있을 것으로 기대된다.

\section{References}

Kim, S. G. (2012), “CPM Schedule Summarizing Function of the Beeline Diagramming Method", Journal of Asian Architecture and Building Engineering, November, 11(2), pp. 367-374.

Kim, S. G. (2010), Advenced Construction Management, Kimoondang.

Kim, S. G., Lee, Y. H, Noh, S. B., Ko, D. G. (2011), “The Concept of Schedule and Cost Progress Integrated Management on the BDM Network", Korean journal of Construction Engineering and Management, KICEM, 12(6) pp. 54-64.

Kim, S. G, Ko, D. G, Lee, Y. H, K, Kweon, I. J. (2012), “Method of Transforming PDMss Overlapping Relationships to BDM;s Relationships", Korean journal of Construction Enginnering and Management, pp. 181-182.

Noh, S. B., Lee, Y. H., Yoo, Y. J., Kim, S. G. (2012), “Schedule Computation Method of Two-way Multiple Relationships on the BDM Network" Korean journal of Construction Enginnering and Management, pp. 179-180.

Park, S. C. (2010), "P3 vs Primavera P6". Korean journal of Construction Engineering and Management, KICEM, 11(4) pp. 37-39.

Shin, D. H., Park, H. S., Koo, K. J., Yoon, S. H. (2010), "Application Plan of TACT Process for Finish Works in Apartment Housing Projects", Korean journal of Architectural Institute of Korea. 26(1) pp. 129-136.

Yoon, Y. S., Suh, S. W (2005), “The application of tact time at finish work for building construction- Focused on Office Building", Korean journal of Construction Enginnering and Management, 6(6) pp.90-97.

요약: 최근 건설사업은 건축, 토목, 기계, 전기, 조경 등의 모든 분야를 포함하는 복합 건설사업으로 추진되고 있고 대형화, 고층화 되 어감에 따라 반복공정이 증가하게 되면서 작업 연속성 확보를 통한 목표공기를 달성하는 $\mathrm{TACT}$ 공정관리기법이 대두되고 있다. $\mathrm{TACT}$ 기법은 반복작업의 자원을 효율적으로 활용하기 위해 작업과 작업이 단절되지 않도록 일정한 작업흐름을 유지할 수 있지만 $\mathrm{CPM}$ 기법에 의해 수립된 네트워크가 아니기 때문에 전진계산, 후진계산, Gritical Path 관리, 여유시간을 알 수 없어 체계적인 공정 관리라 할 수 없다. 본 연구에서는 공동주택의 마감공사 $\mathrm{TACT}$ 공정계획을 기존의 엑셀(Excel), $\mathrm{PDM}$ 기법 기반의 공정관리소프트웨 어인 Primavera(P6), 새로운 공정관리기법 $\mathrm{BDM}$ 기법 기반의 공정관리소프트웨어인 Beeliner로 작성 및 운영하는 방법들을 비교분석 함으로써 $\mathrm{BDM}$ 기법에 의한 $\mathrm{TACT}$ 공정계획 수립 및 운영상 적용성을 제시하고자 한다.

키워드 : $\mathrm{CPM}, \mathrm{TACT}, \mathrm{PDM}, \mathrm{BDM}$, 공동주택 마감공사 